保健物埋, 18, 57 65（1983）

解説

\title{
原子放射線の影響に関する国連科学委員会第 31 回会議
}

\author{
市川 龍 資*1
}

(1983 年 2 月 2 日受理)

The 31st Session of United Nations Scientific Committee on the Effects of Atomic Radiation

Ryushi ICHIKAwA*1

KEY WORDS: UNSCEAR, natural radiation, fallout, nuclear power, medical exposure, occupational exposure

この委員会の活動や報告書についてのこれまでの情報 は,「国連科学委員会 1972 年報告 $\rfloor^{12}(1972)$,「放射線影 響科学委員会の最近の動向」2),「放射線影響国連科学委 員会第 26 回会議」3),および「放射線影響国連科学委員 会第 28 回会議」)に述べてあるので参照していただきた い。

さきに予定されていた 1981 年報告は種々の事情で遅 れ，1982 年報告としてこの秋の国連総会に提出される 運びとなった。第 31 回会議は昭和 57 年 3 月 15 日から 26 日までウィーンの Vienna International Center 会 議場で開かれ, 1982 年報告の内容について最終的なつ めを行った。このセンターはニューヨークの国連ビル, ジュネーヴの国連欧州本部（昔の国際連盟の建物）につ ぐ第三の国連ビルといわれ，ドナウ河をはさんでウィー ン市の向い側にそそり立っている。オーストリア政府が 国際機関を誘致するため国費で建設し，国連に提供して いるすので, IAEA その他の国際機関が入っている。原 子力放射線の影響に関する国連科学委員会の事務局もこ のビルに入っているので, この委員会の会議は現在いつ もこのセンターで開催されるようになった。

\footnotetext{
*1 放射線医学総合研究所環境衛生研究部; 千葉市穴川 49-1 (T260)

Division of Environmental Health, National Institute of Radiological Sciences; 9-1, Anagawa 4-chome, Chiba 260, Japan.
}

今回用いた草案は, 1982 年報告の内容構成になって おり，総会への 報告書主文と，多数の付属書（annex） とから成っている。主文は総会に対する報告であるから 平易にとりまとめた概説であり，付属書は技術的に高度 のもので各分野の専門家に適した内容になっている。付 属書の各題名は次のとおりである。
A. 線量評価モデル
B. 自然放射線源による被曝
C. 人為的に変更された自然放射線被曝
D. ラドン,トロンと娘核種による被曝
E. 核実験による被曝
F. 原子力発電による被曝
G. 医療上の被曝
H. 職業上の被曝
I 、放射線の遺伝的影響
J ．正常組織の照射による非確率的影響
K．放射線による寿命の短縮
L. 放射線之他の物理的, 化学的, 生物的諸因子の組 合せによる生物学的影響

会議は物理グループと生物グループにわかれて行わ れ, 前者が付属書 $\mathrm{A} か ら \mathrm{H}$ をで, 後者が IからLまでを 担当した。筆者は物理グループの会議に参加したので, 主としてそこで取り扱った付属書と，これに関連する主 文の一部について興味あるところを述べることとした。 


\section{1. 線量評価モデル}

この章を設けることはすでに 1977 年報告からはじま っており，被曝線量を計算する各章に共通した基本事項 として線量計算モデル，環境モデルをとりまとめて概説 したものである。また，1982 年報告ではこれまでとち がって新しくSI 単位を用いることとしたこともあって, 報告書中で使われる quantity, unit, symbol の一覧表 をつけることとしている。SI 単位に統一したので従来 の報告書と比較しづらくなるが，それよりもっと本質的 な変更は実効線量当量の導入にふみきったことである。

従来, この委員会の報告書ではすべて葴器吸収線量を示 すことを長らく続けてきて扣り，線量当量も使わないと いらフィロソフィ一を堅持してきた。しかし， ICRP 26 が実効線量当量の概念を設定し, 線量限度やリスク評価 にこれを使いはじめたことを考慮し，またこの委員会と しても, different sources や different practices の間 の集団線量の大小を比較することが可能となるといら利 点を重視し，いくつかの問題をかかえていることを承知 しつつ実効線量当量を1982年報告では使用した。これに ついての議論は, 第 28 回会議でくわしく行われ, その 内容は拙文「放射線影響国連科学委員会第 28 回会議」 ${ }^{4)}$ に紹介してある。途中いろいろの紆余曲折はあったが， 最終的には各章の中で蔵器吸収線量を計算して示すが, それらをとりまとめる際に実効線量当量を計算するとい ら方式をとった。

実効線量当量を計算するには各臓器線量に対する荷重 係数が必要となるが，その值には ICRP が防護基準設 定のために与えた数值をそのまま利用することとした。 ICRP の実効線量当量の概念には遺伀的影響の二世代分 が入っており，また，non-fatal な身体的影響は含まれ ていない。委員会は別に荷重係数をつくることも考えた が，ICRP のそれと区別できるほどの精度の高いものは 設定することが困難であり，放射線源間の相対的比較に は ICRP の值を転用してもとれほど大きな誤りとはな らないであろらという判断によって近似的に用いること とした。

体内被曝線量の算定には ICRP 30 の線量係数を用い た。この線量係数は 50 年間の預託線量を計算するよう につくられてある。委員会の目的は ICRP と異なり集 団線量預託の計算にあるが，集団中の個人の平均寿命は ほぼ 50 年くらいであるから ICRP の線量係数をそのま ま利用できるといら。

\section{2. 自然放射線源による被曝}

大地からのガンマ線による屋外線量率の各国における 測定調查データは 1977 年報告にみられるよりかなり充
第 1 表 大地からのガンマ線による地上 $1 \mathrm{~m}$ での 空気吸収線量率

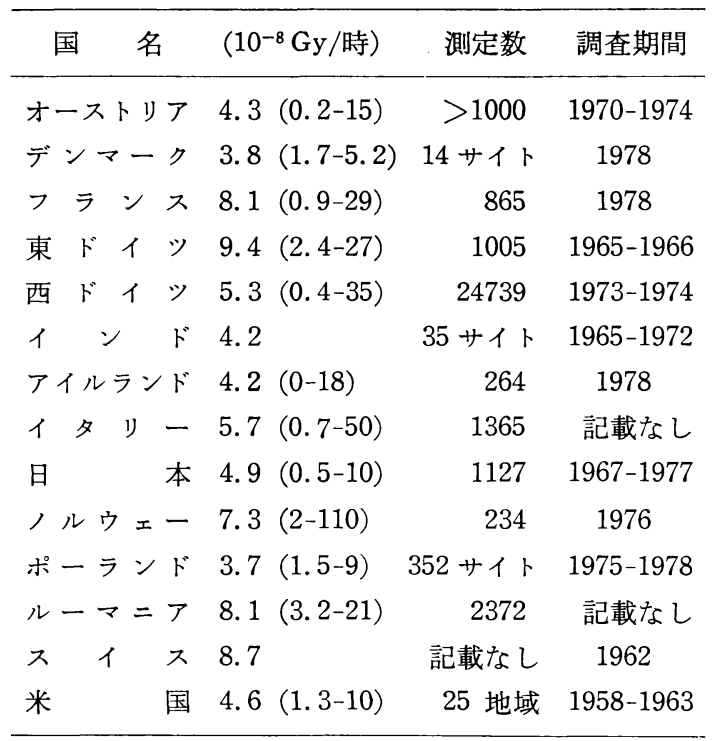

\section{実した（第 1 表)。}

5,000 万以上の人口の国で広く各行政区域にわたって 測定值のある西ドィッ,イタリー，日本括よび米国の空 間線量率を合わせてヒストグラムを作った 1977 年報告 の図を新しいデータを用いて書き直したのが第 1 図であ るが, 1977 年報告のものとその分布形状は変化してい なかった。平均は $5 \times 10^{-8} \mathrm{~Gy} /$ 時くらいである。第 1 表 にみられるように日本は平均レベルに非常に近い。東ド

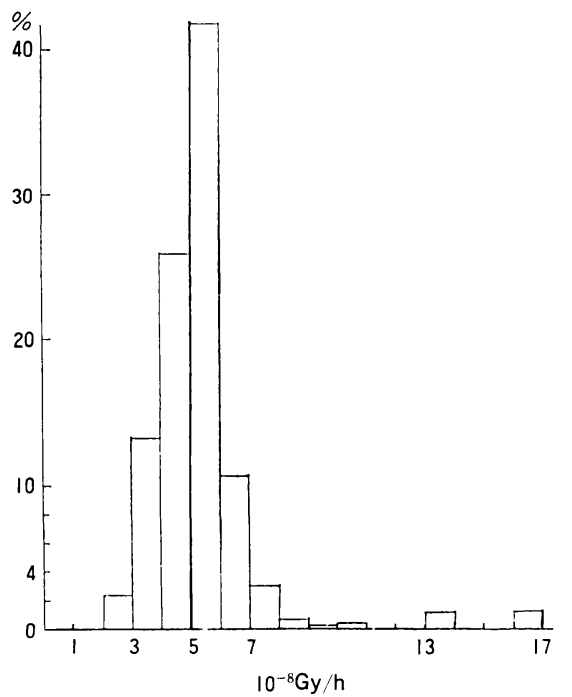

第 1 図大地放射線による空気吸収線量率の人口頻 度分布 $(\%)$ 
イッ, フランス, ルーマニアなどが高く, デンマーク， ポーランドなどが低いよらである。

体外被曝源としての宇宙線, 体内被曝源としての ${ }^{40} \mathrm{~K}$ などあまり問題はないが, 注目されるのはラドン, トロ ンおよびその娘核種である。肺線量寄与が大きいこと, 国によってはとくに高くなるところもあり，くわしいデ 一タが得られつつあるので, 後述するよらに別章にまと めてある。ここでは自然放射線による人体の被曝線量を 総まとめしたとき，ラドン，トロンの寄与分の大きさは 自然放射線被曝全体の約半分に達することが示されてい る(第 2 表)。

こうして総合計は世界全体での平均レベルとして年間 $2 \mathrm{mSv}$ といらことができる。これまで自然放射線被曝線 量は年間 $100 \mathrm{mrem}$ といいならわされているので, 数 字だけみるとあたかも 2 倍に大きくなったかのように䛊 まって解釈されると思われるが，本当のところはそうで はなく，実効線量当量という新しい quantity を用いた ために数字が異なっていることに注意が必要である。

\section{3. 人為的に変更された自然放射線被曝}

この章は 1977 年報告からとりあげられた項目であり，

第 2 表 通常レベルの自然線源による 1 人当りの年 間実効線量当量（世界平均）

\begin{tabular}{|c|c|c|c|}
\hline \multirow{2}{*}{ 線 } & \multicolumn{3}{|c|}{ 年間実効線量当量（ $\mu \mathrm{Sv})$} \\
\hline & 体外照射 & 体内照射 & 合 計 \\
\hline \multicolumn{4}{|l|}{ 宇 宙 線 } \\
\hline 電離 成 分 & 280 & & 280 \\
\hline 中性子成分 & 21 & & 21 \\
\hline 宇宙線生成核種 & & 15 & 15 \\
\hline \multicolumn{4}{|l|}{ 地球起源核種 } \\
\hline${ }^{40} \mathrm{~K}$ & 120 & 180 & 300 \\
\hline${ }^{87} \mathrm{Rb}$ & & 6 & 6 \\
\hline \multicolumn{4}{|l|}{${ }^{238} \mathrm{U}$ 系列 } \\
\hline${ }^{238} \mathrm{U} \rightarrow{ }^{234} \mathrm{U}$ & ) & 10 & ) \\
\hline${ }^{230} \mathrm{Th}$ & & 7 & \\
\hline${ }^{226} \mathrm{Ra}$ & 90 & 7 & 1,044 \\
\hline${ }^{222} \mathrm{Rn} \rightarrow{ }^{214} \mathrm{Po}$ & & 800 & \\
\hline${ }^{210} \mathrm{~Pb} \rightarrow{ }^{210} \mathrm{Po}$ & & 130 & \\
\hline \multicolumn{4}{|l|}{${ }^{232} \mathrm{Th}$ 系列 } \\
\hline${ }^{232} \mathrm{Th}$ & ) & 3 & ) \\
\hline${ }^{228} \mathrm{Ra} \rightarrow{ }^{224} \mathrm{Ra}$ & 140 & 13 & 326 \\
\hline${ }^{220} \mathrm{Rn} \rightarrow{ }^{208} \mathrm{Tl}$ & & 170 & 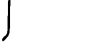 \\
\hline 合 & 650 & 1,340 & 2,000 \\
\hline
\end{tabular}

石炭火力発電, 燐酸工業, 建材, 航空機利用, および雑 線源（夜光塗料など）が対象となっているが，今回の報 告書でははじめて地熱発電も含められた。

石炭火力発電による集団線量は $\mathrm{U}, \mathrm{Th}, \mathrm{Ra}, \mathrm{Rn}$ など の吸入, 沈着後の体外被曝, 食物連鎖による体内被曝を 含めて $2 \mathrm{man} \mathrm{Sv} / \mathrm{GW}$ 年と見積もられ，1979 年におけ る世界全体での集団線量は，2,000 man Sv になるとい う。興味ある点は, 石炭火力発電の場合, 大気中の ${ }^{14} \mathrm{C}$ の specific activity を低下させる作用があるから，マイ ナスの線量預託が生じることになることである。

なお, 石炭火力発電所 (1 GWe) 近傍のクリティカル グループの個人被曝線量は, 吸入により 1 年間に $5 \mu \mathrm{Sv}$ であり，食物連鎖と外部被曝もそれと同程度といら。

さらに，石炭はヨーロッパなどでは暖房用にも使用さ れて扣り, 発電所とちがってその灰の $50 \%$ も一般環境 に放出されるから，1977 年の世界全体での暖房利用に よる集団線量は $10^{5}$ man Sv と計算され，発電利用より 大きくなるが, この值は, きわめて大ざっぱな計算であ るという。

地熱発電はアイスランド, イタリー, 日本, ニュージ ーランド，米国，ソ連にあり， ${ }^{222} \mathrm{Rn}$ の放出がとくに重 要であるといら。イタリーの経験では $1 \mathrm{GW}$ 年の発電量 当り $4 \times 10^{14} \mathrm{~Bq}\left(10^{4} \mathrm{Ci}\right)$ のラドンの放出があり, 集団

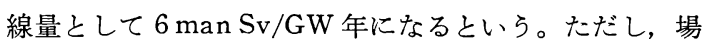
所によって放出量は異なるであろらから，どこでもこう なるとは限らないと考えられる。また, 個人線量として は, $100 \mathrm{~m}$ の高さのスタックから $1 \mathrm{~km}$ の地点にいる人 に対し, $1 \mathrm{GW}$ 年の地熱発電所の 場合 $3 \times 10^{-5} \mathrm{~Sv} \mathrm{(3}$ mrem) と計算される。

\section{4. ラドン, トロンと娘核種による被曝}

ラドン, トロンとその娘核種は屋内における濃度が重 要で, それらの吸入による肺の線量がかなり大きいこと が特徵である。いくつかの国で住居内のラドン濃度（娘 核種が平衡に達している状態に換算してある）の測定值 が得られて扣り，第 3 表にまとめたように，特別に高い スウェーデンは別として, お括かたの住居内濃度測定值 は $5 \sim 25 \mathrm{~Bq} / \mathrm{m}^{3}(0.1 \sim 0.7 \mathrm{pCi} / l)$ くらいの範囲にあり, これは年間実効線量当量にして $0.3 \sim 1.5 \mathrm{mSv} \quad(30 \sim$ $150 \mathrm{mrem})$ に相当している。中緯度地域の集団に対し ては平均して $15 \mathrm{~Bq} / \mathrm{m}^{3}$ が妥当なレベルであり, 戸外の $1.8 \mathrm{~Bq} / \mathrm{m}^{3} \quad(0.05 \mathrm{pCi} / l)$ の 8 倍の水準にあたる。それ ゆえ, 年間実効線量当量は屋内（生活時間の $80 \%$ をこ こで過ごすとする）について $0.92 \mathrm{mSv}$, 屋外（生活時

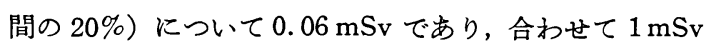
がラドンと娘核種による線量寄与と計算される。中緯度 
第 3 表 家屋内ラドン濃度と実効線量当量率

\begin{tabular}{|c|c|c|c|c|}
\hline & 国 & & $\begin{array}{l}\text { 濃 度* } \\
\left(\mathrm{Bq} / \mathrm{m}^{3}\right)\end{array}$ & $\begin{array}{l}\text { 実効線量 } \\
\text { 当量率 } \\
(\mathrm{mSv} / \text { 年) }\end{array}$ \\
\hline \multicolumn{3}{|c|}{ オーストリア } & 12 & 0.73 \\
\hline \multicolumn{3}{|c|}{ カ ナ ダ } & 17 & 1.0 \\
\hline \multirow{2}{*}{\multicolumn{3}{|c|}{$\begin{array}{l}\text { デンマーク } \\
\text { フィンランド }\end{array}$}} & 4.8 & 0.3 \\
\hline & & & 17 & 1.0 \\
\hline \multicolumn{3}{|c|}{ 西 ド イ ッ } & 8.1 & 0.5 \\
\hline \multirow{2}{*}{\multicolumn{3}{|c|}{ ハンガリ-- }} & $\int 20$ & 1.2 \\
\hline & & & 120 & 7.3 \\
\hline \multirow{2}{*}{\multicolumn{3}{|c|}{ ルルェ ー }} & $\int 11$ & 0.7 \\
\hline & & & $\{26$ & 1.6 \\
\hline \multirow{2}{*}{\multicolumn{3}{|c|}{ 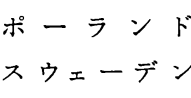 }} & $6-17$ & $0.4-1.0$ \\
\hline & & & 60 & 3.7 \\
\hline \multirow{2}{*}{ 英 } & \multirow{2}{*}{\multicolumn{2}{|c|}{ 国 }} & $\{15$ & 0.9 \\
\hline & & & $\{13$ & 0.8 \\
\hline 米 & & 国 & 15 & 0.9 \\
\hline \multirow{2}{*}{\multicolumn{2}{|c|}{ y }} & \multirow{2}{*}{ 連 } & $\{4.8$ & 0.3 \\
\hline & & & $\{16$ & 1.0 \\
\hline 数 & か & 国 & 18 & 1.1 \\
\hline
\end{tabular}

* 平衡等価濃度

地域とちがって赤道地域はデータがないが，気候から推 定して屋内のラドン濃度は屋外とかわらないくらい低い

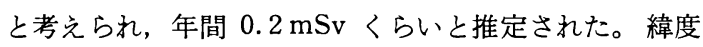
別人口分布の重みをつけると, 全世界平均のラドンによ る線量は, 約 $0.8 \mathrm{mSv} /$ 年としてよいであろう。

トロン濃度はラドンの $1 / 20$ くらいなので, 中緯度地 域で屋内濃度が $0.7 \mathrm{~Bq} / \mathrm{m}^{3}$ くらいであり, 線量にして $0.2 \mathrm{mSv}$ にあたるという。全世界平均にして $0.17 \mathrm{mSv}$ とした。

省エネルギーは多くの 国で重要な課題となっている が，その一環として屋内空気の換気率をある程度抑制す ることにより暖房用電力の消費をかなり低減することが できる。スウェーデンはェネルギー資源に乏しく，冬季の 寒さもきびしい国であるから，集合住宅の屋内換気率の 規制値を引き下げることによる省エネルギー政策を考兄 ている。この場合, 屋内ラドン濃度が当然のことながら 上昇するから，居住者の 被曝線量も增加する結果とな る。スウェーデンに括ける試算では, 節約電力 $1 \mathrm{MW}$ 年当り $5.6 \mathrm{man} \mathrm{Sv}$ の線量增加となるといら。ただし， これは地域条件でちがらから他の国にはあてはまらな い。

\section{5. 核実験による被懪}

大気圈内核実験がほとんど行われなくなったので成層 圏に滞留している人工放射性物質は少量となり, 生成さ れた量の大部分はすでに地球上に降下してしまっている のが現状である。それゆ光，環境中放射性核種濃度や人 体の被曝線量に大さな变化はなく, 徐々に長期的に減少

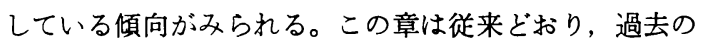
核実験による将来までも含めた人類の線量預託を推定す るのが目的であるから，その構成と内容は 1977 年報告 のそれと大きく変わっていない。括もな相違点は ${ }^{54} \mathrm{Mn}$

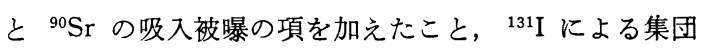
線量の推算を試みたことが挙げられる。

そのほか改訂した点として，1977 年報告における核 実験由来の ${ }^{3} \mathrm{H}$ による線量預託の 計算がまちがって拈 り、これを訂正したのでその值は以前より 2 倍に大きく なった。これは自然の ${ }^{3} \mathrm{H}$ 生成量を北半球分と地球全体

第 4 表 核実験による世界平均の実効線量当量預託

\begin{tabular}{lcc}
\hline \multicolumn{1}{c}{ 核 } & $\begin{array}{c}\text { 央効線量当量預託 } \\
(\mu \mathrm{Sv})\end{array}$ & $\begin{array}{c}\text { 奇与の割合 } \\
(\%)\end{array}$ \\
\hline${ }^{14} \mathrm{C}^{*}$ & 2,600 & 69 \\
${ }^{137} \mathrm{Cs}$ & 540 & 14 \\
${ }^{95} \mathrm{Zr}$ & 200 & 5.3 \\
${ }^{90} \mathrm{Sr}$ & 120 & 3.2 \\
${ }^{106} \mathrm{Ru}$ & 83 & 2.2 \\
${ }^{144} \mathrm{Ce}$ & 54 & 1.4 \\
${ }^{3} \mathrm{H}$ & 47 & 1.2 \\
${ }^{131} \mathrm{I}$ & 33 & 0.9 \\
${ }^{239} \mathrm{Pu}$ & 27 & 0.7 \\
${ }^{140} \mathrm{Ba}$ & 25 & 0.7 \\
${ }^{103} \mathrm{Ru}$ & 17 & 0.4 \\
${ }^{240} \mathrm{Pu}$ & 17 & 0.4 \\
${ }^{241} \mathrm{Pu}$ & 9 & 0.2 \\
${ }^{55} \mathrm{Fe}$ & 9 & 0.2 \\
${ }^{241} \mathrm{Am}$ & 4 & 0.1 \\
${ }^{89} \mathrm{Sr}$ & 3 & 0.08 \\
${ }^{141} \mathrm{Ce}$ & 1 & 0.03 \\
${ }^{238} \mathrm{Pu}$ & 1 & 0.03 \\
${ }^{136} \mathrm{Cs}$ & 0.06 & 0.002 \\
${ }^{54} \mathrm{Mn}$ & 0.04 & 0.001 \\
${ }^{85} \mathrm{Kr}$ & 0.005 & 0.0001 \\
\hline${ }^{\mathrm{A}}$ & 300 & 100 \\
\hline${ }^{*} \mathrm{i}+$ & 800 & \\
\hline
\end{tabular}

* 西暦 2000 年まではこの $7.7 \%$ 
分ととり違えたことによる䛊りである。また， ${ }^{90} \mathrm{Sr} に よ$ る骨表面の線量は, 従来 1 strontium unit 当り 1.95 $\operatorname{mrad}$ といら線量係数を用いて計算してきたが，ICRP 30 に打いてこの線量係数を 1 strontium unit 当り 2.8 $\operatorname{mrad}$ と改訂したので, この委員会もこの線量係数を用 いることとした。

核実験により生成された各放射性核種による線量の総 まとめを第 4 表に示す。值は，実効線量当量であらわさ れるている。全世界平均の線量預託として合計 $3.8 \mathrm{mSv}$ となる。表にみられるように ${ }^{14} \mathrm{C}$ による奇与が全体の $70 \%$ を占めているが，この線量は数千年に及ぶ長い期 間にわたって与えられるもので，他の核種による線量と 性格が異なることに注意が必要である。西暦 2000 年ま でに与えられる線量はそのらちの $7.7 \%$ にすぎない。

\section{6. 原子力発電による被曝}

原子力発電所々の他の施設からの単位発電量当りの放 射性核種放出量は，各国から集められた 1975〜1979 年 の間の放出実績を平均して求めた值を標準值として使用 した。

1977 年報告における 評価と異なる点は， 線量預託が きわめて長期間にわたる場合，いくつかの期間に区切っ て，それぞれの時期までの線量預託を示したこと，これ までの報告書は集団線量のみ計算していたのに対し，施 設近傍の個人線量についてもある一定の条件下でその值 の見積りを示したこと，事故に関して TMI， ウィンズ ケールの場合の放出と集団線量の評価を行ったこと, 放 射性廃棄物の処分，貯蔵についての集団線量についても 少しふれたことなどが挙げられる。

なお，局地的地域的の集団線量の計算に際して 1977 年報告では人口密度を 100 人 $/ \mathrm{km}^{2}$ とし，100 km まで 加算していたが，今回は EC の調査にもとづき，施設 からの距離ごとの人口密度を実際に近いように設定し， $2,000 \mathrm{~km}$ まで含めるようにしている。

トリチウムの大気放出による局地的, 地域的集団線量 預託が 1977 年報告における值よりかなり大きくなった のは，人口密度や計算範囲の距離をこのように変えたこ とのほかに, 1977 年報告が吸入経路のみとりあげて線 量算定をしていたのに対し，今回は specific activity 法を採用してすべての経路を含めたことによっている。

各然料サイクル段階ごとに主要核種の局地的，地域的 集団線量預託を計算して表示したのが第 5 表である。ま た世界人口全体への寄与と，廃棄物処分による集団線量 預託を第 6 表に示した。

このような線量預託を考えるとき，いつも問題となる のは超長寿命核種の寄与をどうとり扱えばよいかといら
第 5 表 原子力発電による単位発電量当りの集団実 効線量当量預託一(1) 局地, 地域的寄与

集団実効線量当量預託 (manSv/GWe 年)

採鉙
ラドン
0.5

製鍊

$\begin{array}{ll}\text { ウラン, トリウム, ラジウム } & 0.015 \\ \text { ラドン } & \end{array}$

燃料加工

ウラン

0.002

原子炉運転

大気放出

希ガス

0.6

トリチウム

0.5

炭素 14

2.8

ヨウ素

0.06

微粒子

0.1

水域放出

$\begin{array}{ll}\text { トリチウム } & 0.04 \\ \text { その他 } & 0.02\end{array}$

核燃料再処理

大気放出

$\begin{array}{ll}\text { トリチウム } & 0.1 \\ \text { クリプトン } 85 & 0.03 \\ \text { 炭素 } 14 & 0.2 \\ \alpha \text { 核種 } & 0.002\end{array}$

水域放出

$\begin{array}{ll}\text { セシウム } 134,137 & 0.4 \\ \text { ルテニウム } 106 & 0.3 \\ \text { ストロンチウム } 90 & 0.02 \\ \alpha \text { 核種 } & 0.0006 \\ \text { ヨウ素 } 129 & 0.008 \\ \text { 送 } & 0.003\end{array}$

合計

5.7

点である。たと党ば, ${ }^{129} \mathrm{I}$ (半減期 $1.6 \times 10^{7}$ 年) や ${ }^{230} \mathrm{Th}\left(8 \times 10^{4}\right.$ 年)， ${ }^{238} \mathrm{U}\left(4.5 \times 10^{9}\right.$ 年）を含む製鍊残査 からでてくるラドンの線量寄与がそれである。ラドンそ のものは半減期が短いが，それを発生させるもとのウラ ンが長く残存寸るからである。超長寿命の核種からの線 量預託をこのようにきわめて長期間にわたって計算し加 算することにどらいう意義があるかという問題である。 
第 6 表 原子力発電による単位発電量当りの集団実効線量当量預託一(2) 世界人口への寄与と廃棄物処分

実効線量当量預託 (manSv/GWe 年)

\begin{tabular}{|c|c|c|c|c|c|}
\hline & \multicolumn{5}{|c|}{ 実効線量当量預託（manSv/GWe 年） } \\
\hline & & & 積 算 其 & 間 （年） & \\
\hline & 10 & $10^{2}$ & $10^{4}$ & $10^{6}$ & $10^{8}$ \\
\hline \multicolumn{6}{|l|}{ 世界人口への寄与 } \\
\hline トリチウム & 0.015 & 0.02 & 0.02 & 0.02 & 0.02 \\
\hline クリプトン 85 & 0.9 & 1.9 & 1.9 & 1.9 & 1.9 \\
\hline 炭素 14 & 3 & 10 & 70 & 110 & 110 \\
\hline ヨウ素 129 & - & 0.02 & 0.21 & 28 & 560 \\
\hline 合 計 & 3.9 & 12 & 72 & 140 & 670 \\
\hline \multicolumn{6}{|c|}{ 廃棄物処分（再処理実施, Pu 利用） } \\
\hline 製錬残査（ラドン） & 0.25 & 0.25 & 250 & 2,800 & 2,800 \\
\hline （ウラン） & & & 460 & 460 & 460 \\
\hline 高レベル廃棄物 & - & - & - & 30 & 30 \\
\hline
\end{tabular}

すなわち，数 10 万年さきに対して現在の評価モデルが あてはまるとは考えられないし，また数 10 万年かかる 線量を一括してとりあつからこと自体に疑問が生ずる。

それゆえ, 将来における年間線量率の最高値を知る目 的に重点をおいて線量預託を評価するのであれば，放出 をもたらす practice（ここでは原子力発電事業）が継続 するかもしれないと考えられる期間で積分するといら方 式をとることができる。この目的のためにはこの報告書 では原子力発電の継続する期間を長くみて 500 年として 線量預託を求めることを試みた。

核然料サイクルの操業段階（つまり，廃棄物処分を別 にして）から放出される核種による局地的，地域的な集 団線量預託は発電量/GWe 年当り $5.7 \mathrm{man} \mathrm{Sv}$ と計算 され，その大部分が数年のうちに与えられるといら。こ れは対しグローバルに抬散する核種（トリチウム，クリ プトン 85, 炭素 14 ，ヨウ素 129）による 500 年間の部 分集団線量預託は, $1 \mathrm{GWe}$ 年当り $18 \mathrm{man} \mathrm{Sv}$ と計算さ れた。

これに対し，製錬残査から放出されるラドンについて は，将来増殖炉が開発使用されることになり採鉱が減る ことを考慮して積分期間を 100 年にとって部分集団線量 預託を計算すると $0.25 \mathrm{man} \mathrm{Sv} / \mathrm{GWe}$ 年となり，悲観的 に 500 年間の積分を行うと, 約 $2.5 \mathrm{man} \mathrm{Sv/GWe}$ 年 になるという。

高レベル廃棄物についての評価は INFCE のものを引 用し, $10^{5} \sim 10^{6}$ 年の閉じ込め能力を期待し, その後, 淡 水に霂洩し, ついで海に入る経路についての集団線量が

\section{第 6 表に計算してある。}

個人線量の評価としては，仮定された原子力発電所モ デルサイトにて, critical group の個人に対し, 希ガス から年間数 $10 \mu \mathrm{Sv}$, トリチウムから $10^{-6} \mathrm{~Sv}$ （重水炉 は, $\left.10^{-4} \mathrm{~Sv}\right), \exists ウ$ 素から BWR は $10^{-5} \mathrm{~Sv}, \mathrm{PWR}$ は それ以下，液体放出から $5 \mu \mathrm{Sv}$ 以下といら打执よその 水準を示しているが，これは個々の施設の性格やサイト 周辺環境の条件によって異なるはずである。再処理施設 についても critical group の個人に対し, 大気放出から 年間 $25 \mu \mathrm{Sv}$, 海域放出について $200 \mu \mathrm{Sv}$ といら数字を 例として示したが，もちろんサイトにより異なるのは当 然である。

\section{7. 医療上の被曝}

診断用 X線, 診断用核医学, 放射線治療による被曝に 関し、これまでに遗伝有意線量なる概念を導入し，つい で平均骨䯣線量を用いた。また 1977 年報告では甲状腺, 肺, 乳房など他の器官の線量もできるだけ評価すること となった。1977 年報告を出して以後今回まで身体的有 意線量 (somatically significant dose) の設定の可能性 について種々検討が行われた。日本がこれまで計算し発 表してきた白血病有意線量はその一種であり, がん有意 線量の推定の試みもその途中にある。しかし，まだ情報 が不十分なので一般的な身体的有意線量の設定はできな かった。また ICRP の設定した実効線量当量は, 各器官 の線量に荷重係数を適用して合計したものであり, 遺伝 的リスクも二世代分が含まれているものであって, 委員 会の目的とは異なる立場からつくられたものであるから 
遺伝的リスクの分を削除したり，致死的でないがんのリ スクを含めたりして荷重係数の訂正を行う試みもなされ たことがある。しかし，荷重係数の異なる実効線量当量 を別に設定することは混乱を招きやすいし，委員会が患 者の不均一な照射による全リスクを評価する立場から必 要とする荷重係数を設定するのに十分な精度が得られる ほどの情報は存在しないことを考虑すると ICRP の荷 重係数を準用しても大きな違いは生じないであろらと考 えた。それゆえ, その欠点を認識しつつも, 遺伝有意線 量と器官線量とのみ示すよりも, 実効線量当量を使用す るほうがより実りあるものと考光た。ただしこの場合， 患者の被曝なので，ほんとらのリスクを必ずしも示さな いことがあるのに注意をはらら必要がある。

方式としてはこのように医療被曝も実効線量当量を用 いてあらわすことになったが，それに必要なデータつま り診断や治療時の各器官の線量が十分得られていないの が実情であることが判明した。最もよく各器官の線量を 報告している例があるのは日本とポーランドであり，報 告書にはこの 2 カ国の例について計算し，その結果を示 すこととした。

委員会としては, 今後, 各国で医療上の照射のデータ をとりまとめる場合，できるだけ遺伝有意線量と実効線 量当量の值を示して欲しいこと，あるいは，少なくとも それらが推算可能になるデータを含めて欲しいことを表 明した。

医療用放射線照射による個人当りの実効線量当量は発 達した国で扮拈よそ $1 \mathrm{mSv} /$ 人・年くらいのオーダーで あり，国によって 0.5 2.0 mSv の開きがあろう。低開 発国ではそれより一桁くらい低いであろうという。

\section{8. 職業上の被曝}

1977 年報告で用いた 職業被曝線量の 頻度分布の標準 型 (reference distribution) は対数-正規分布, 平均 $5 \mathrm{mGy} ， 50 \mathrm{mGy}$ を超える人は $0.1 \%$ といらものであ るが，前報告の計算に誤りがあり訂正された。日本から 提出してあった原研熊沢氏の 対数一正規分布と正規分布 の組合せによる職業被曝線量のあてはめについては, 実 際の被曝線量に 適用するにはたんなる 対数一正規分布よ りょく合うであろうと考えられ，これについて記述する ことにした。

核然料サイクル各段階での職業被曝は, 第 7 表のよう になって损り, 合計で $1 \mathrm{GWe}$ 年の発電量当り約 30 $\operatorname{man} \mathrm{Sv}$ 弱といらことができる。現在の世界の原子力発 電量が $70 \sim 100 \mathrm{GWe}$ 年とすると，これに伴う職業被曝 集団線量は $2,000 \sim 3,000 \mathrm{man} \mathrm{Sv} /$ 年くらいと見積もら れる。
第 7 表 核燃料サイクル各段階における職業人の単 位発電量当りの集団実効線量当量

\begin{tabular}{cc}
\hline 事 業 & $\begin{array}{c}\text { 単位発電量当りの } \\
\text { 集団実効線量量 } \\
(\mathrm{manSv} / \mathrm{GWe} \text { 年) }\end{array}$ \\
\hline 採鉱, 製錬 & 1 \\
然 料 加 工 & 1 \\
原子炉運転 & 10 \\
燃料再処理 & 10 \\
原子力研究 & 5 \\
合 & $\sim 30$ \\
\hline
\end{tabular}

医療職業被瀑は，国によって大きく異なるが，医療の

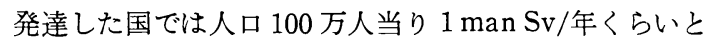
いう。

工業利用の職業被曝は発達した国にて人口 100 万人当 り $0.5 \mathrm{man} \mathrm{Sv} /$ 年くらいである。

特殊な職業被曝としては航空機乗務員の $1 \sim 2 \mathrm{mGy} /$ 年, 空港の荷物検查員の年間 $1 \mathrm{mGy}$ 以下, 金属鉱山鉱 内夫の年間 $1 \mathrm{WLM}$ のラドン被曝，ラドン泉従業者の 20 WLM（これは，ウラン鉱山の鉱夫より高いという）, 燐酸肥料取扱作業者の年間 $0.2 \mathrm{mGy}$ などの例が挙げら れている。

事故被曝については 1977 年報告にはふれられていな いが，今回の報告では原子力産業，工業ラジオグラフィ 一, 研究開発における主要な事故例をとりまとめて表に している。日本からは, 1971 年のイリジウム事故の例 が入っている。

\section{9. 主文（総会への報告畫）}

全体の構成は，付属書各章を平易に概説したものと， その総括文からできている。

1977 年報告では, 種々の線源からの線量預託を自然 放射線被曝の日数で表現して比較した。今回の報告書に 抢いても類似の方式で各線源による実効線量当量の相対 的比較を二通りの図にあらわすことを試みている。

第 2 図では集団実効線量預託を次の線源についてその 発生した各年毎に棒グラフにして示した。ただし，自然 線源と診断用放射線は各年とも一定として横線であらわ してある。

(a) 自然放射線への 1 年間の被曝

(b) 診断用放射線の 1 年間の使用

(c) 1 年間の核爆発

(d) 原子力発電の 1 年分

単位は自然放射線 1 年分の被瀑を 365 日とした。大気 圈内核実験による 1 年分の集団実効線量当量預託は1962 


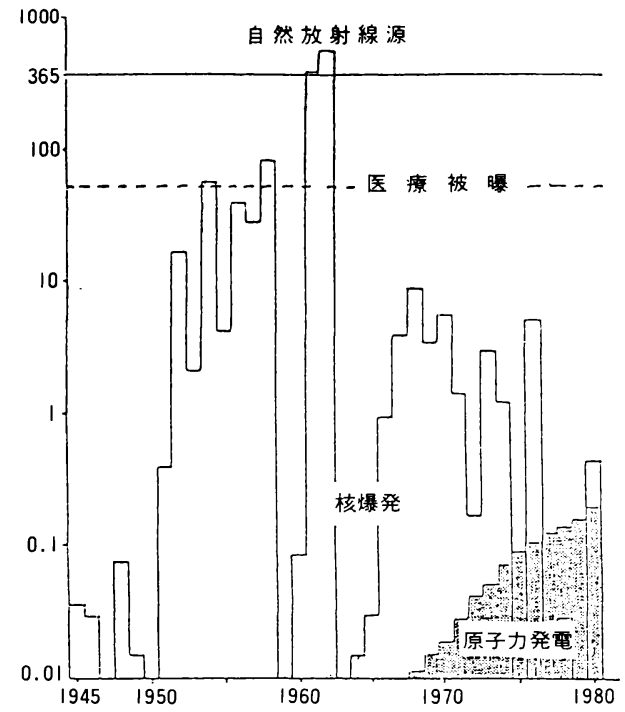

第 2 図 1 年間の行為当りの集団実効線量当量預託 の変動（自然線源の日数で表示）

年にピークがあり，自然放射線被曝の約 1 年分に近かっ た。原子力発電による集団実効線量当量は, 年ごとに増 加しているもののまだ自然放射線によるもののわずかな フラクションでしかない。

また, さらに各年における年間実効線量当量の変化を 示したグラフが第 3 図である。自然放射線によるものに 対するパーセントであらわしてある。核実験による年間 実効線量当量は 1963 年をピークとして下降している。 原子力発電によるものはしだいに増加する傾向を示して

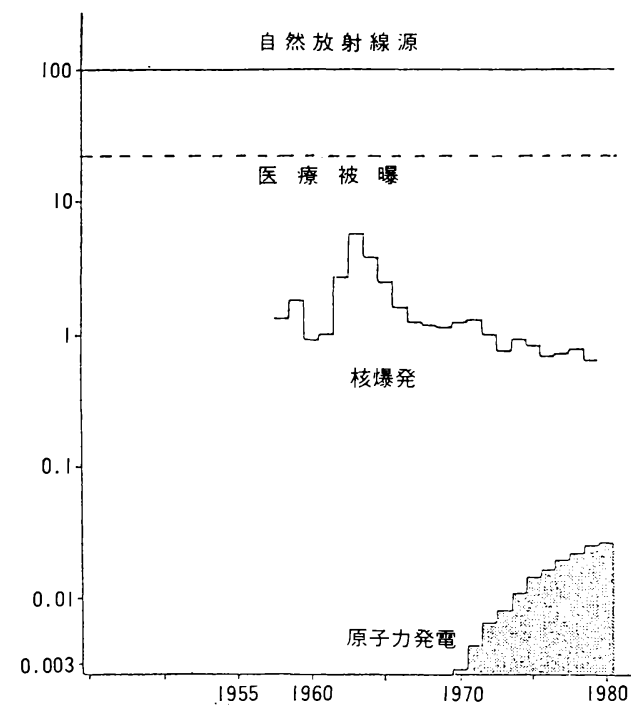

第 3 図 年間実効線量当量の年変化（自然線源に対 する \% で表示)
いるが，まだそのレベルは他の三線源に比してはるかに 低い。

人工放射線のらち最大の被曝寄与のあるのは医療とく に診断用放射線であり，それによる個人当りの年間実効 線量当量は $0.4 \mathrm{mSv}$ であり，自然のそれの約 $20 \%$ で ある。委員会はまだこれを減少させる余地は十分あると 考えている。

1980 年までに行われた 核実験による 集団実効線量当 量預託は将来の人口増加も計算に入れると現在の人口に 打ける自然放射線被曝集団線量の約 4 年分に相当する。 このうち約 0.4 年分はすでに照射ずみであり, あとの大 部分は ${ }^{14} \mathrm{C}$ にるものであるといら。

1980 年における世界の原子力発電容量は $140 \mathrm{GWe}$ で あり,これによる 1 年間の発電に伴う 500 年間の部分集 団実効線量当量預託は自然放射線被曝の約 5 時間分に相 当するといら。これには職業被曝も含めてある。西暦 2000 年に $1,000 \sim 1,600 \mathrm{GWe}$ の発電容量に達すると すると,これによる線量預託は自然放射線のお扣よそ 2 日分に匹敵することになるが，それまでに技術開発が進 むであろらから, 実際にはもっと小さくなると考えられ る。

\section{0. 生物グループでの検討}

生物グループでは付属書 $\mathrm{I}, \mathrm{J}, \mathrm{K}, \mathrm{L}$ を討議し書き改 めたわけであるが，以前に予定されていた「放射線発が んにおける線量一反応関係」の章は, 最近米国で実施さ れている広島, 長崎の線量再評価の仕事がその結果をま とめるまで一時延期することとし，1982 年報告には含 めないことなっている。

遺伝的影響については 1977 年報告以降に得られた多 くの情報を加え, これまでに行ってきた仮定, 手法およ びリスク推定值の確実さを増加させることができたとい 5 。

正常組織の照射による非確率的影響については, 実験 動物での臓器の非確率的影響とそのしきい值のデータを とりまとめて示し，人については一時的および永久的不 妊を扣こす線量のデータをレビューした。人についての 非確率的影響のデータがきわめて不足しているという。

放射線による寿命の短縮については, 実験動物で得ら れた多数の証拠によると, 低〜中程度の線量(率)の照射 でおこる寿命の短縮は串質上がんによることが示されて おり, 広島, 長崎の調査結果も同じ結論を支持している といら。

放射線之他の物理的, 化学的, 生物的諸因子との組合 せによる生物学的影響については, そのデータがばらば らで一貫性がない。ある条件下でタバコの煙が，放射線 
と相乗的に作用することがありらるが，それ以外には少 なくとも有意な大きさの集団におけるリスク推定值を大 きく変えそうな関係を示す実例はみあたらないという。

\section{1.おわりに}

次回の第 32 回会議は 1983 年 6 月 20 日から 24 日ま での予定でウィーンの Vienna International Center で 開かれることになり，32，33 回会議に打ける議長に D. BENINSON アルゼンチン代表が, 副議長に熊取敏之日本 代表が，ラポターに A. HIDAYATALla スーダン代表が 選出された。1982 年報告の発表のあと, どのようなテ 一マについて検討し，次の報告に何をもり込むかという 点から論議がはじまることになるが，事務局で草案を用
意することになる。

\section{参 考 文 献}

1）市川龍資; 国連科学委員会 1972 年報告, 保健物 理, 7, 199 (1972).

2）市川龍資；放射線影響科学委員会の最近の動向, 保健物理, 10, 54 (1975).

3）市川龍資；放射線影響国連科学委員会第 26 回会 議, 保健物理, 12, 139 (1977).

4）市川龍資; 放射線影響国連科学委員会第 28 回会 議, 保健物理, 14, 203 (1979). 